\title{
KESEIMBANGAN KOMUNIKASI DALAM PENGUATAN IDENTITAS KOMUNITAS KREATIF TELEMATIKA KOTA MALANG
}

\author{
Saudah, Dodot Sapto Adi \\ Program Studi Ilmu Komunikasi FISIP Universitas Merdeka Malang \\ saudah@unmer.ac.id
}

\begin{abstract}
The creative industry of telematics has become a cornerstone of hope in accelerating the improvement of the national socio-economy, as stated in the Presidential Instruction Number: 6/2009, and followed by the Minister of Industry Regulation Number: 16 / MIND / PER / 2/2011 concerning the electronics and telematic industries, because it has the opportunity to overcome labor problems through the technopreneurship movement. Ethnographic studies on the balance of communication in strengthening identity, have been able to reveal the existence of the creative community of telematics in the city of Malang to show a central role in social change. Through the actions of institutional relations constructed, it was able to carry out integrated engineering, proceeding towards the strengthening of socio-cultural identity, and demonstrating it by mastering information and communication technology (ICT) as its medium. This is the urgency of the study results which in fact can be followed through the daily life of creative beings as representations of the community. By using a subjective-interpretive approach, involving 9 key informants as members of the creative community who have strong relationships with 3 business-based telematics industries. Through a study that has been implemented for 2 years, has given 3 offer the concept of development, among others: (1) activation of facilitation to increase the capacity of human resources; (2) strengthening relations and communications to an adaptive community network; and (3) access to capital and production as a stimulant for community institutions.
\end{abstract}

Keywords: communication balance, strengthening identity, creative community of telematic

\begin{abstract}
ABSTRAK
Industri kreatif telematika menjadi tumpuan harapan dalam mempercepat peningkatan sosial ekonomi nasional, sebagaimana tertuang dalam Inpres RI Nomor: 6/2009, dan disusul Permenperin RI Nomor: 16/M-IND/PER/2/2011 tentang industri elektronika dan telematik, karena berpeluang mengatasi problematika ketenagakerjaan melalui gerakan technopreneurship. Studi etnografi mengenai keseimbangan komunikasi dalam penguatan identitas, telah dapat mengungkap keberadaan komunitas kreatif telematika di kota Malang untuk menunjukkan peran sentral dalam perubahan sosia
\end{abstract}


Melalui tindakan relasi kelembagaan yang dikonstruksikannya, ternyata mampu melakukan rekayasa terintegratif, berproses menuju semakin menguatnya identitas sosiokultural, dan mempertunjukkannya dengan menguasai teknologi informasi dan komunikasi (TIK) sebagai medianya. Inilah urgensi dari hasil studi yang faktanya dapat diikuti melalui kehidupan sehari-hari insan kreatif sebagai representasi komunitas. Dengan menggunakan metode pendekatan subjektif-interpretif, melibatkan 9 informan kunci sebagai anggota komunitas kreatif yang memiliki relasi kuat dengan 3 industri telematika sudah berbadan usaha. Melalui studi yang telah dilaksanakan selama 2 tahun ini, telah memberikan 3 tawaran konsep pengembangannya antara lain: (1) penggiatan fasilitasi untuk meningkatkan kapasitas SDM; (2) memperkuat relasi dan komunikasi menuju jaringan komunitas yang adaptif; dan (3) akses permodalan dan produksi sebagai stimulan bagi kelembagaan komunitas.

Kata kunci: keseimbangan komunikasi, penguatan identitas, komunitas kreatif telematika

\section{PENDAHULUAN}

Penelitian yang dilaksanakan pada kurun waktu tahun 2016-2017 mengenai keseimbangan komunikasi dalam dinamika relasi sosial, khususnya yang dilakukan pelaku industri dengan komunitas kreatif telematika di kota Malang, semakin menarik untuk diungkapkan dari sisi individu yang melibatkan lingkungan sosialnya. Interaksi yang terjalin melibatkan problematika paling mendasar dilandasi motif ini, akan membentuk relasi hingga tingkatan tertentu dan berdampak pula pada intensitas komunikasi. Relasi dan komunikasi inilah yang merefleksikan rutinitas diantara para pelaku, juga mengungkap proses terjadinya hubungan resiprositas, menampilkan karakteristik yang bervariasi mulai dari tingkatan profesionalisme, orientasi tindakan yang mengarah pada perilaku sosial maupun Keseimbangan Komunikasi dalam Penguatan Identitas Komunikasi Kreatif bisnis, membentuk nilai-nilai yang dinormakan secara bersama-sama melalui negosiasi, memperkuat posisi komunitas yang sudah ada sampai dengan tumbuhnya komunitas baru, dan semua mempertunjukkan identitas individu maupun kelompok sosialnya. Basis komunitas menjadi pertimbangan paling menentukan, dan menjamin terselenggaranya pengembangan industri kreatif telematika secara berkesinambungan, yaitu berorientasi pada peningkatan potensi sumberdaya manusia (SDM) dengan dilandasi kearifan lokal.

Industri kreatif telematika berada dalam rumpun ekonomi kreatif telah dirintis oleh Departemen Perdagangan R.I. sejak 8 Juni 2008, melalui konvensi yang berhasil merumuskan Rencana Pengembangan Ekonomi Kreatif 2025. Bahkan Kementerian Koordinasi Bidang Ekonomi menerbitkan kebijakan, bahwa 144 
seluruh BUMN wajib menumbuhkan kembangkan Incubator Business Center (IBC), fokusnya pada fasilitasi bagi wirausaha pemula (startup entrepreneur) golongan mikro kecil menengah (IMKM) sebagai penyangga utama kekuatan ekonomi nasional. Langkah awal paling menentukan, adalah meletakkan basis komunitas kreatif menjadi target program fasilitasi, dengan mengutamakan penyempurnaan talenta pelaku industri maupun penggiat wirausaha. Pentingnya memperkuat hubungan pelaku industri dengan komunitas kreatif telematika, semata-mata ditujukan untuk mengendalikan kesinambungan dalam rangka penumbuhan dan pengembangannya. Dalam kurun waktu beberapa tahun belakangan ini, menegaskan bahwa kegiatan ekonomi lokal sampai nasional akan memperoleh jaminan keberlanjutan, apabila mampu memanfaatkan setinggi-tingginya keberadaan komunitas kreatif telematika (Pangestu, 2008).

Memperhatikan dengan seksama perkembangan komunitas penggiat kreatif telematika, khususnya di wilayah kota Malang yang termuat dalam berbagai pemberitaan online maupun cetak, menjadi terbuka ketika Pemerintah Provinsi Jawa Timur pada tanggal 11 Maret 2013 mendeklarasi sebuah Program Rintisan Industri Kecil Berbasis Teknologi Tinggi yang diberi nama Jawa Timur Information Technology Creative (JITC), dan program fasilitasinya berpusat di jalan Raya Galunggung 8 Malang. Misi utamanya untuk menumbuhkan dan mengembangkan industri kreatif telematika pertama di wilayah Jawa Timur. Demikian pula penggiat kreatif telematika yang mengoperasional JITC Malang, adalah insan-insan muda kreatif yang tergabung dalam lembaga Inkubator Kewirausahaan Teknologi Informasi dan Komunikasi (IK-TIK) Malang. Program penumbuhan dan pengembangan industri kreatif telematika yang berbasis pada komunitas, terdistribusi ke dalam 3 (tiga) wilayah sasaran program kerja antara lain: (1) Malang Raya berpusat di kota Malang; (2) Pesisir Utara Timur berpusat di kota Probolinggo; (3) Dataran Tengah Barat berpusat di kota Jombang; dan (4) Dataran Selatan Barat berpusat di kota Blitar (Supanto dkk, 2017).

Perjalanan waktu melalui berbagai lokakarya dalam rangka merumuskan model paling tepat, maka pada awal Februari 2016 PT. Telkom Indonesia membuka ruang fasilitasi serupa dengan mendirikan Digital Innovation Lounge (DILO), kegiatannya berpusat di jalan 
Basuki Rachmad 7-9 Malang. ilmiah, bahwa tumbuh berkembangnya Memperhatikan pertumbuhan yang sangat industri telematika hanya bisa terjadi signifikan, maka Pemerintah Kota Malang dalam jaringan pelaku komunitas kreatif. pada awal April 2016 juga menyusul Komunitas memiliki kekuatan sumberdaya mendeklarasi dibukanya forum Indonesia insani yang mandiri, dan mampu Creative City Conference (ICCC), berkontribusi bagi kesejahteraan dimaknai sebagai upaya sistematis menuju lingkungan sosialnya dalam berbagai kota kreatif berwawasan global melalui keaneragaman potensi lokal, dan salah satunya kegiatan pengembangan industri telematika di kota Malang. Selanjutnya pada pertengahan tahun 2017 juga telah beroperasi pertama kali Rumah Kreatif BUMN (RKB), dengan dimotori oleh Bank Rakyat Indonesia (BRI) membuka ruang fasilitasi bagi komunitas pelaku usaha sektor ekonomi mikro, skala kecil, serta menengah (UMKM). Pusat kegiatannya berada di jalan Raya Langsep kota Malang, dan komunitasnya lebih banyak dari kalangan perempuan yang memiliki sikap responsif terhadap program pemerintah. Untuk itulah kebijakan pemerintah diarahkan memperkuat koordinasi dan komunikasi yang berimbang, khususnya bagi pelaku industri yang berorientasi bisnis dengan komunitas kreatif telematika, mengingat perkembangan ekonomi lokal sangat dipengaruhi oleh stabilitas politik global.

Gambaran realita tersebut masih bentuk relasi. Kondisi ini sebagaimana digambarkan melalui hasil studi Saudah (2017), yaitu mengenai masa transisi kelembagaan ekonomi semi modern yang menitik beratkan pada relasi dan komunikasi pelaku ekonomi, bahwa pada masyarakat di wilayah perkotaan sekalipun tetap tidak akan pernah lepas dari nilai-nilai yang sudah terlembagakan sebagai budaya lokal. Jalinan relasional dalam bentuk formal lebih sering dilakukan untuk kegiatan sosial, sedangkan yang lebih berorientasi bisnis dilakukan secara informal. Hal ini memberikan makna, bahwa dalam proses relasi yang berorientasi bisnis (achievement) pada hakekatnya tidak dibiarkan mengganggu norma sosial yang telah ada (ascription), dan selanjutnya menjadi kebiasaan yang terpolakan di dalam relasi komunitas. Jaringan inilah yang kemudian membentuk pola koneksi dalam hubungan individu, kelompok ataupun berbagai bentuk kolektif lain. tersembunyi dalam berbagai hasil kajian 
Pada tahun 2017 telah dapat dirumuskan pola peran kelembagaan yang populer disebut dengan formula quadruple helix dengan sinerjitas Business, Intelectual, Goverment, and Community $(B I G C)$. Salah satu kajian oleh Supanto \& Fristin, 2017) menegaskan, bahwa terdapat satu elemen sosial penting mengenai keberadaan komunitas penggiat kreatif telematika yang sudah lama terbentuk secara mandiri dan bersifat mengakar. Berkegiatan dengan saling memberi fasilitasi sebagai sesama pelaku, memperkuat eksistensinya dengan membentuk jaringan dalam bidang kreativitas yang sejenis, dan hampir semua rata-rata mengawali kegiatannya dari pertemanan, persaudaraan, dan kekeluargaan (familyhood principle). Kondisi demikian ini lebih memposisikan nilai-nilai bersifat askriptif (social motive) sebagai yang dominan, dengan berusaha keras secara bersama-sama untuk memperoleh manfaat materiil atau finansial (achievement motive). Mempertemukan empat elemen sesuai dengan gambaran BIGC Model tersebut sebagai alternatif solusi terbaik, masih bisa dipahami apabila menemui kendala dalam rangka menjadikannya sebagai sebuah kekuatan sosial ekonomi lokal, karena masih banyak faktor-faktor lain di luar komunitas maupun industri seperti situasi politik dan kebijakan yang berkaitan.

Relasi dan komunikasi diantara pelaku industri dan komunitas kreatif telematika secara institusional, akan membentuk pola interaksi yang kondusif serta memiliki kekuatan untuk mengatasi setiap persoalan yang sedang berada dalam situasi krisis. Khususnya mengenai dinamika interaksi yang tumbuh dan berkembang pada lingkup komunitas kreatif telematika di kota Malang, dapat diteliti lebih mendalam mengenai eksistensinya yang difokuskan pada: (1) identitas yang dikomunikasikan dalam rangka memperkuat relasi dengan pelaku industri; dan (2) mengkonstruksikan perannya secara resiprositas-berimbang (ballancing on reciprocity communicative) baik di dalam institusi komunitas maupun hubungannya dengan industri.

\section{METODE}

Studi lapang tersebut dimaksudkan untuk mengungkap kehidupan sehari-hari yang dipraktikkan secara cerdas, dan ini dapat digunakan oleh pelaku sendiri untuk menjelaskan (menjabarkan, mengkritik dan mengideasi) situasi-situasi yang lebih bersifat khusus. Atas dasar tersebut, dapat ditetapkan metode penelitiannya dengan menggunakan pendekatan paradigma pos- 
positivistik (post-positivism paradigm), dengan memposisikan diri sebagai bagian dari realita yang dijadikan sasaran penelitian (Guba \& Lincoln dalam Pujileksono, 2015:26-28). Mengingat posisi objek sangat dekat dengan kehidupan sehari-hari peneliti, maka akan lebih memadai bila segala proses analisis teoritiknya dilakukan secara kualitatifetnografis. Pendekatan ini lebih menempatkan komunitas kreatif telematika sebagai insan yang aktif, dengan mengandalkan kemampuan intelektualnya untuk dapat memenuhi semua harapan-harapannya. Proses kajian ini akan selalu menjadi tumpuan menemukan konsep-konsep yang tersembunyi, sehingga membentuk rangkaian yang mampu mendeskripsikan serta menjelaskan fenomena (Denzin, 2009:337).

Metode tersebut dapat menjamin terungkapnya keyakinan setiap orang sesuai dengan kompetensinya berinteraksi secara praktis, dan memungkinkan hakikat realitas kehidupan sehari-hari dapat diserap, dipahami, dan keteraturannya direproduksi. Penentuan informan bergantung pada kapasitas interpretifnya dalam berinteraksi, sehingga dapat merangkai atau menyingkap keteraturan sosial. Untuk memenuhi itu semua, maka informan penelitian merupakan anggota komunitas kreatif telematika yang memiliki intensitas hubungan dengan pelaku industri yang sudah memiliki badan usaha antara lain: (1) Cakrawala Creative; (2) Efrat Multimedia; dan (3) Hexagonal. Dengan menentukan 9 (sembilan) informan anggota komunitas kreatif telematika, khususnya memiliki relasi kuat dengan pelaku industri yang berorientasi bisnis, maka dapat dikelompokkan berdasar jaringan pada 3 (tiga) kegiatan kreatif telematika antara lain: videografi, animasi, dan digital illustrasi.

\section{PEMBAHASAN}

\section{Identitas Dalam Relasi dan Komunikasi}

Identitas dapat diibaratkan sebagai konsep orijinal yang dapat memberikan deskripsi tentang individu maupun kelompok masyarakat tertentu. Juga menjadi petunjuk bersifat mendasar dalam rangka memahami dinamika perubahan yang terjadi. Demikian pula pada komunitas kreatif telematika yang sangat akrab dengan perkembangan teknologi, dengan jumlah terbesarnya berada di wilayah kota yang memiliki kegairahan pembangunan di bidang industri maupun pendidikan, dan salah satunya selalu bersentuhan dengan pemanfaatan teknologi informasi dan komunikasi 
sebagai perangkat utama. Pentingnya mengungkap pertumbuhan dan perkembangan komunitas kreatif telematika di kota Malang, maka telah memperoleh informasi lapang yang cukup signifikan untuk dapat dijadikan pedoman dalam menggambarkan identitas masingmasing.

Komunitas kreatif bidang videografi memberikan gambaran, bahwa hampir secara menyeluruh gerakannya masih relatif tersembunyi, namun akhir-akhir ini justru bidang videografi menjadi semakin terbuka, karena tuntutan pasar menghendaki kehadiran secara nyata. Untuk itu tidak dapat dipungkiri pelaku di bidang ini, semakin banyak yang tampil di dalam ruang yang terbuka, karena untuk merespons aspirasi pasar terhadap identitas sesungguhnya, bahkan sudah banyak yang mulai hijrah ke industri formal dengan memiliki badan usaha. Komunitas videografi sangat peka dengan kemajuan teknologi digital, dan menjadikan setiap hasil produksinya sebagai bagian penting dari upaya mempertunjukkan kompetensinya dalam mengadaptasi teknologi terbaru.

Komunitas kreatif yang bergerak mengembangkan animasi sangat berbeda, yaitu sejak awal sudah membuka diri dengan masyarakat luas, sehingga mudah dideteksi keberadaannya termasuk bisnis yang dikembangkannya. Identitas pelaku lebih cenderung bersifat individual, kalaupun didominasi oleh kelompok hanya terbatas yang memiliki latar belakang keahlian seni desain, dan selanjutnya dikembangkan menuju ranah bisnis berbasis teknologi digital. Uniknya penggiat animasi justru terletak pada perbandingan terbalik antara jumlah pelaku dan badan usaha, dalam artian bahwa terjadi percepatan jumlah anggota komunitas namun tumbuhnya badan usaha masih relatif sedikit.

Komunitas kreatif yang sebelumnya bergerak di lingkup visual ilustrasi, pada tahap selanjutnya bergeser menjadi digital ilustrasi yang memiliki kebijakan tersendiri dalam mengungkap pandangan dunianya. Memang anggota komunitas memposisikan dirinya yang cenderung sangat tersembunyi, dan dapat diibaratkan sebagai komunitas yang berbicara melalui karya. Kecenderungan ini cukup dapat dipahami oleh pelakunya sendiri, dengan mengungkapkan keyakinan atas sebuah komitmen sebagai komunitas seni dari pada komunitas digital. Keterbukaannya kepada masyarakat luas, hampir secara keseluruhan menggunakan media karya artistiknya. Pergeseran menuju ranah digital, bagi anggota komunitas hanya 
sebuah proses inovasi tanpa menurunkan derajat seni visualnya.

Memperhatikan tiga kelompok identitas komunitas tersebut, maka lebih mudah untuk mengungkap mengenai makna atas simbol-simbol yang dipahami serta dipikirkan oleh masing-masing anggota komunitas kreatif telematika, yaitu dalam rangka menentukan tindakan masing-masing saat interaksi berlangsung. Simbol bermakna yang diciptakan, dipikirkan, dan dipahami di lingkungan internal maupun eksternal komunitasnya, akan menunjukkan kekhasan dalam perilaku komunikasi. Memahami identitas yang berbentuk jalinan simbol verbal maupun nonverbal, menjadikannya menempati posisi yang sangat penting dalam bentuk relasi homofili, seperti setiap anggota komunitas dapat saling berkomunikasi dan mewariskan nilai-nilai kepada komunitas yang baru atau sedang akan tumbuh (Littlejohn \& Foss, 2009:130-132). Dengan demikian akan semakin terbuka, yaitu mengenai ungkapan makna dari anggota komunitas berdasarkan pandangan dunianya sendiri, dan juga pandangan pihak lain di luar diri maupun komunitasnya. Pelaku lebih sering menunjukkan sifat mementingkan komunitasnya sendiri (communalinterested), dan berupaya memberikan suatu peningkatan pada hasil yang dinilai positif dan mengurangi hasil-hasil yang bersifat negatif tanpa karakter (Ritzer, 2012:155). Dari pemahaman inilah dapat menjawab tegas, mengenai identitaas komunitas kreatif telematika dalam berinteraksi yang sarat dengan komitmen bersama. Hal ini mengisyaratkan adanya konstruksi diri melalui interpretasinya terhadap situasi, dan interpretasi dibangun melalui proses bersama secara resiprokal atau timbal balik (Turner, 2012: 339).

\section{Konstruksi Keseimbangan Peran Komunitas}

Komunitas kreatif telematika di kota Malang pada kenyataannya dapat dengan leluasa memainkan peran dalam memperkuat hubungan sosial, yaitu dengan cara berbagi informasi serta saling memberikan manfaat kepada yang lain. Pada dasarnya komunitas merupakan bentuk gugusan kecil, memiliki jaringan yang disesuaikan dengan jenis kreativitasnya, memiliki orientasi sosial ekonomi yang mandiri, saling mengikatkan diri dalam bentuk jaringan kerja, dan keberadaannya terbebas dari batas-batas wilayah geografis maupun standar etnis dominan. Hal ini sejalan dengan hasil studi Adi (2017), bahwa jaringan sosial hanya bisa terbentuk 
dengan adanya proses pemberdayaan yang ditujukan pada komunitas kreatif telematika, yaitu dengan melibatkan berbagai unsur dalam bentuk kegiatan aktif, juga memiliki orientasi sama menuju terciptanya keseimbangan peran individu maupun kelompok. Pendekatan relasional dalam kelembagaan komunitas, sangat ditentukan oleh keberhasilan melakukan interaksi yang dinaungi komitmen bersama, dengan saling mengikatkan diri secara resiprositas sampai terbentuknya struktur jaringan yang selalu disempurnakan.

Pada lembaga bisnis sebenarnya tinggal melanjutkan program unggulan manajemennya, karena perusahaan sudah memiliki kegiatan yang terhimpun dalam corporate social responsibility (CSR). Dalam studi yang dilakukan oleh Saudah dan Adi (2012) mengungkapkan, bahwa program yang bersifat sosial memiliki dampak yang signifikan dalam rangka memperkuat reputasi dan meningkatkan citra perusahaan, walaupun pada dasarnya program tersebut ditujukan secara tegas bagi komunitas luar perusahaan. Hal ini disebut sebagai investasi sosial yang memberikan kemanfaatan luas, yaitu tidak terbatas pada keuntungan bersifat finansial tetapi juga pada terjaminnya kelangsungan hidup perusahaan. Dengan mengadopsi hasil studi tersebut, maka sekurangkurangnya industri telematika di kota Malang akan memperoleh 3 manfaat besar antara lain: (1) terarahnya kendali manajemen industri untuk memperkuat reputasi apabila mengindahkan aspirasi dan potensi komunitas kreatif yang memiliki aktivitas sejenis di bidang telematika; (2) terwujudnya kedekatan emosional antara manajemen industri dan komunitas kreatif telematika setempat, apabila perusahaan dapat menyerap sumberdaya lokal maupun hasil-hasil karya komunitas untuk memenuhi kelangkaan inovasi produksinya; dan (3) terjaminnya keamanan dan kenyamanan beroperasinya kegiatan industri telematika apabila didukung partisipasi komunitas yang memiliki kesamaan visi dan misi.

Peran hanya akan ditemukan dalam berbagai bentuk tindakan, dapat berorientasi sosial yang disebut askriptifinteraksionis, bertumpu pada berjalannya hubungan antarindividu atau juga kelompok membentuk pola peran sesuai dengan relasi yang dibangun. Hubungan industrial antara pelaku bisnis dan komunitas, setidaknya tentang jaringan terlembaga yang terus berkembang atas dasar fungsinya bagi kelangsungan hidup komunitas itu sendiri. Apabila pola dilihat dalam konteks skema tindakan umum, 
maka akan masuk ke dalam pola hubungan timbal balik (Susilo, 2008:109). Penerapan askripsi memiliki acuan kepada sistem sosial komunitas itu sendiri, dan berkaitan dengan nilai yang diyakini. Kompleksitas hubungan fungsional akan semakin tampak, apabila dikaitkan dengan proses komunikasi. Ketika komunikasi berlangsung, maka diantara orang yang terlibat akan saling mendefinisikan hubungan yang ada dengan cara melakukan pertukaran simbol bermakna berkomunikasi (Littlejohn, 2009:189).

Sebenarnya anggota komunitas kreatif telematika dapat memainkan peran keseimbangan relasi dan komunikasi dengan baik serta tuntas, khususnya di dalam kehidupan komunitasnya sendiri maupun pada lingkup industri bisnis. Secara individual dapat melakukan hubungan dalam segala aspek sesuai kebutuhannya, baik untuk kepentingan eksistensi komunitasnya maupun untuk pengembangan bisnis yang dikonstruksi bersama pelaku industri, juga mengembangkan koneksi internal maupun memperluasnya samapai lingkup eksternal. Anggota komunitas yang inovatif dapat semakin leluasa menyempurnakan norma-norma atau aturan main dalam jaringan komunitas, dan dapat membentuk pola perilaku yang menjadi karakternya dalam rangka mewujudkan harapannya. Bisa jadi komunitas yang menaunginya semakin berkembang, yaitu menjadi lembaga yang mampu menampung aspirasi bagi dirinya sendiri maupun pihak lain, baik dalam bentuk formal maupun informal seperti ikatan profesi industri kreatif telematika. Untuk mempertahankan komunitasnya, maka membentuk ikatan sosial dengan individu sebagai proses rekrut baru, atau dengan membangun generasi baru.

\section{SIMPULAN}

Komunitas kreatif telematika memiliki peran penting untuk mengkonstruksi keseimbangan komunikasi dalam penguatan identitasnya. Kondisi yang berkembang saat ini justru memposisikannya sebagai medanpsikososial yang strategis. Hal ini mempertimbangkan kemandirian komunitas untuk menentukan arah penumbuhan dan pengembangan penggiatan kreatif telematika, yaitu melalui upaya peningkatan kapasitas SDM yang didukung program fasilitasi secara berkesinambungan dari elemen lainnya. Fakta yang tidak terbantahkan terletak pada kebijakan pemerintah yang melibatkan unsur BUMN, dengan ditopang oleh lembaga pendidikan pada 
level menengah hingga perguruan tinggi. Model quadruple helix (BIGC) yang intens diimplementasikan, telah benar-benar mensejajarkan komunitas kreatif sebagai SDM utama, tentu dengan segala identitas yang memperkuat eksistensinya diharapkan memperbaiki peradaban ekonomi berbasis potensi lokal mulai tingkat nasional sampai dengan daerah. Melalui studi yang telah dilaksanakan selama 2 tahun ini, telah memberikan 3 tawaran konsep pengembangannya antara lain: (1) penggiatan fasilitasi untuk meningkatkan kapasitas SDM; (2) memperkuat relasi dan komunikasi menuju jaringan komunitas yang adaptif; dan (3) akses permodalan dan produksi sebagai stimulan bagi kelembagaan komunitas.

\section{DAFTAR PUSTAKA}

Adi, Dodot Sapto. 2017. Quadruple Helix Model In Inspiring The Development of Telematics Creative IndustriesCommunity Base (The Study of Phenomenology On Industrial Startup In Malang. Proceeding International Conference: "Sustainable Development Goals On 2030 Challange and Its Solution". ISBN: $\quad 978-979-3220-41-3$. https://www.researchgate.net/public ation/319242518. Accessed: August, 2, 2018 at $05.30 \mathrm{pm}$

JITC Malang. 2013-2017. Kliping Dokumen Komunitas: Media Cetak dan Online.

Littlejohn, Stephen W. and Foss, Karen A. 2009. Teori Komunikasi. Jakarta: Salemba-Humanika.

Pangestu, Mari Elka. 2008. Pengembangan Ekonomi Kreatif Indonesia Tahun 2025. Hasil Konvensi 4-8 Juni 2008.

Departemen Perdagangan R.I: http://dgi.or.id/wpcontent/uploads/2015/05/hasilkonvensi pengembangan-ekonomikreatif1.pdf. Diakses tanggal 16 Januari 2017 pukul: 12.34 .

Pujileksono, Sugeng. 2015. Metode Penelitian Komunikasi. Malang: Intrans Publishing.

Supanto, Fajar, dan Fristin, Yuntawati. $2017 . \quad$ Community-based Acceleration Model of Entrepreneurship Growth and Development on Telematics Creative Industries in Malang Raya Indonesia. JAES. Volume XII, Issue 7 (53), Winter (2017), ISSN-L 1843$6110, \quad$ ISSN 2393-5162. https://www.researchgate.net/public 
ation/323238293. Accessed: August, 2, 2018 at $05.08 \mathrm{pm}$.

Supanto, Fajar dan kawan-kawan. (20162017). Perencanaan Fasilitas Pendukung Unit Pelaksana Teknis Information Technology (UPT-IT) Provinsi Jawa Timur: (Laporan Akhir Hasil Penelitian). Dinas Perindustrian dan Perdagangan Provinsi Jawa Timur.

Susilo, Rachmad K.D. 2008. 20 Tokoh Sosiologi Modern. Yogjakarta: ArRuzz Media.

Saudah. 2017.. Personal Factors On The Behavior of Interactionist Traders In A Traditional Market Environment and Semi Modern (Ethnographic Study On The Tradisional Market In Malang Regency. Proceeding: Sustainable Development Goals On 2030. ISBN: 978-979-3220-41-3. https://www.researchgate.net/public ation/324644858. Accessed: August, 2,2018 at $05.25 \mathrm{pm}$.
Saudah dan Adi, Dodot Sapto. 2012. Konstruksi Tanggungjawab Sosial Untuk Peningkatan Komersialisasi Perusahaan. Jurnal Bisnis\&Manajemen. Volume 1, Nomor 1, Juni 2012 ISSN:18297528.

https://www.researchgate.net/public ation/319902979. Diakses: 2 Agustus 2018 pukul: 17.18.

Norman K Denzin. 2009. Handbook Of Qualitative Research. Yogjakarta: Pustaka Pelajar.

George Ritzer. 2012. Handbook Teori Sosial. Bandung: Nusa Media.

Turner, Bryan S. 2012. Teori Sosial Dari Klasik Sampai Postmodern.Yogjakarta: Pustaka Pelajar. 